\title{
木造密集地域の共同建替えに係る委託型組合方式の事業性に関する研究 FEASIBILITY OF BUILDING COOPERATIVE SYSTEM IN AREAS WITH HIGH DENSITY OF WOODEN HOUSES
}

\author{
小滝 晃*, 織 山和 久** \\ Akira KOTAKI and Kazuhisa ORIYAMA
}

\begin{abstract}
It is essential to fireproof wooden buildings that could spread fires within blocks of buildings in order to prevent widespread fires and fire whirlwinds caused by an earthquake. Although fireproofing requires joint rebuilding projects that will consolidate lots without road access, conventional large scale redevelopments cannot match (1) the intentions of land owners to create a people-friendly townscape, (2) site conditions that are small, irregular, and specific, and (3) careful financial planning tailored to the needs of various residents including the aged. Our study proves that cooperative methods of rebuilding may effectively function to meet the requirements with professional support and land consolidation under these conditions. A detailed simulation of specific sites in areas densely crowded with wooden buildings in Tokyo indicates that the cooperative method of rebuilding improves the benefits to every stakeholder and ensures project profitability. Further analysis has identified the determinants of project feasibility and confirmed that the method works more effectively for sites with higher land prices and a higher areal ratio of land without road access.
\end{abstract}

Keywords : areas with high density of wooden houses, joint rebuilding, building cooperative, net present value, reverse mortgage 木造密集地域，共同建替え，委託型組合方式，現在価值，リバース・モーゲージ

\section{1. はじめに}

木造密集地域における大規模な地震火災の防止には、街区内部の 木造建物の不燃化が重要である ${ }^{1)}$ 。そしてこの防災効果を上げるには、 延焼過程ネットワーク（図 1) の八ブ（延焼が及ぶ距離内に多くの隣 接木造建物が位置する木造建物）に相当する延焼危険建物を選択的 に不燃化することが望ましい2)。しかしながら、こうした延焼危険建 物は、接道条件が厳しく単独建替えが困難な区画に建つ場合が多く、 接道区画まで区画統合した共同建替え事業と寸る必要がある ${ }^{\text {i } 11 。 ま ~}$ た、これらの区画の多くは狭小注2)で、事業規模が大きくなると地権 者が多数になって合意形成が難しくなりや寸い ${ }^{3)}$ 。従って、延焼危険 建物の不燃化を促進するためには、区画統合についての合意形成が 促されるためには、各地権者に十分な便益が生じ、その事業規模が 小さくても成立する共同建替え事業方式が望まれる。本研究におい ては、こうした小規模な共同建替え事業の方式とその事業性を検証 する。

試算を行う前に、まず、分譲方式、自力型組合方式及び委託型組 合方式の 3 方式のうち、こうした小規模共同建替え事業の条件に最 も適う事業方式を比較・選定する。次に、東京都区内において共同 建替え事業が最も困難と考えられる箇所を抽出し、選定された事業 方式のもとで新旧各地権者にとっての事業性を詳細に検証する。さ らに東京都区部の木造密集地域において、この方式の一般的な成立 可能性を確認する。

\section{2. 既往研究と本研究の位置づけ}

先行研究は、木造密集地域における共同建替えの可能性と条件を 明らかにしてきた。

(1)共同建替え意向 木造密集地域では、半数の住民が共同建替えを 推進すべきとする地区もあり ${ }^{4)}$ 、建替えや転居を 3 割近くが検討する 例も報告されている5

(2)低層の街並みへの選好＼cjkstart住民の多くは、低層で路地空間の豊かな 住環境やコミュニティを重視し、中高層の街並みを評価する人は $5 \%$

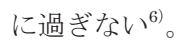

(3)転入動向 こうした地域の環境は、地縁のある住民に好まれ、3 割 強の循環層のうち同一区内からの住み替えが $85 \%$ 、同一地区内が $59 \%$ 、同一町内が $24 \%$ となっている ${ }^{5)}$ 。木造長屋が密集する地区一 の新規流入者のうち 8 割を $20 \sim 40$ 代が占め、新規流入者が「まち なみの風情が好き」「オリジナルな空間がつくれる」としている地区 もある ${ }^{7)}$ 。転入後は、街並みや人の温かさ、祭り、歴史等の魅力を知 り、若年子育て層ほど路地が多く、家の前で子どもが遊びや寸い等 の魅力を認識している ${ }^{8)}$ 。

(4)組合方式の適用可能性 組合方式は、利益や広告費が不要で民間 の建設業者よりも安価（一般に $10 \sim 20 \%$ 程度）で9)、参加者の数も 少なく事業化の合意形成もしやすく、居住者間の交流による安心感 とコミュニティ意識の醸成といった利点が実例から示されてい る ${ }^{10111}$ 。都心型コープ住宅 4 事例はいずれも整形地におけるマンショ

\footnotetext{
* 国土交通省大臣官房総括監察官

** (侏アーキネット 代表取締役
} 
ンタイプだが、平均住戸数 11.5 戸と比較的小規模な事業規模の下で 成立している ${ }^{12)}$ 。

(5)接道区画地権者の利害 しかし接道区画側地権者は、道路後退に よって建築面積が縮小寸ることを敬遠するため、諸施策（連担設計 制度、一団地型地区計画、建築基準法第 43 条但書等）を講じても建 替え事業は成立しにく(13)14)15)16)17)。

(6)資金計画 ある木造密集地域の居住者アンケート調查 ${ }^{18)}$ では、 $65.8 \%$ の居住者が建替え意向を示さない。その理由は、現在の居住 環境に満足 $(28.3 \%)$ 、高齢 $(18.2 \%)$ 、経済的理由 $(18.2 \%)$ 、敷地 の状況により建替えが困難 $(5.4 \%)$ 等とされる。地権者が高齢、無職、 自己資金不足や身寄りがないという場合でも資金計画が成り立つ必 要がある。

(7)大規模事業の限界 共同建替え一の補助事業（密集市街地整備促 進事業、都市防災不燃化促進事業、都心共同住宅供給事業、優良建 築物整備事業、密集市街地整備促進事業等）では適用地区は商業系 用途地区内で容積率が高く、1,000 $\mathrm{m}^{2}$ 以上で地権者 20 名以下の地区 が多く ${ }^{19)}$ 密集市街地内の適用事例は年 10 件程度にとどまる ${ }^{20)}$ 。京島 地区では半数以上の住民が共同建替えを望むが、成功事例は 2 例に 過ぎない)。

(8)道路拡幅の限界 細街路の拡幅整備を行う事業の多くが幅員 $6 \mathrm{~m}$ 以上の路線確保を目指しているが21)、立ち退きによるコミュニティ 分断への地元の反発も強い注 3 )。道路整備の進捗は概ね数十\%に留ま り、道路拡幅に至りにくい22)。沿道で大規模な建替えが展開され、 敷地分割、用途転用、空き地活用によって道路後退もないままミニ 開発が進み木造密集地域が再生産される例もある5

以上の研究成果から、共同建替えへの意向は十分にあり (1)、木 造密集地域の低層の街並みを生かした事業化は新旧の居住者に評価 されること (2(3))、組合方式に可能性があること（4)）が明らかに された。そしてさらに共同建替え事業を広範に展開寸る条件として、 接道区画を含むどの地権者にも十分な利益が生じ、より小さな事業 規模でも成立できること (5)(6)(7))、道路拡幅がなくても事業化でき ることが望ましいこと（8)）が明らかにされている。

本研究はこうした知見を踏まえて、街区内奥の接道不良区画群を も対象にした共同建替え事業として、小規模で、非整形地を対象と するものであっても、接道区画を含む各地権者に利益が生じる方式 を検討する。

\section{3. 共同建替え事業の条件}

木造密集地域における延焼危険度の高い建物（ハブ）は、街区内 奥に位置して接道条件が厳しく単独建替えが困難な場合が多い。し たがって接道条件を満たすよう隣接地との敷地統合を行った上で共 同建替えを行う必要がある。こうした区画群を対象としても共同建 替え事業が成立するためには、前節で述べた条件（(5)～(8)）の下で、 小規模性、非整形性、利益性といった条件に適した事業方式である ことが求められる。

（i）小規模性 隣接地との区画統合を伴う共同建替え事業では、隣 接地権者との複雑な調整や合意形成を要する。したがって対象とな る権利者が多くなると合意形成は困難になり、権利者が少ない共同 建て替え事業の方が合意は形成しや寸い。こうした小規模の建替え は、低層の街並みと調和し居住者にも好まれる ${ }^{6)}$ 。こうした小規模な
共同建替えを連鎖させて延焼危険建物群を選択的に不燃化すれば、 大規模な面的整備事業より短期間で街区全体の不燃化が進む可能性 がある ${ }^{23)}$ 。

(ii ）非整形性 街区全体ないし街区内の大半を対象とする事業であ れば、周囲を公道に囲まれた整形地になり、標準的な直方体の建築 計画が成り立ちや寸い。しかし、接道区画と接道不良の数区画を統 合する小規模な共同建替え事業の場合は、外周に凸凹の多い非整形 地になる場合が多い。こうした千差万別の非整形地に対応した建築 計画手法、標準形より多少割高の工事費でも経済性に劣らない事業 方式であれば適用範囲は広げられる。

（iii）利益性 共同建替え事業が、新旧いずれの地権者に対しても利 益をもたらす必要がある。すなわち区画統合による資産差益や共同 建替えによる容積消化率の向上による利益が、道路後退が必要な接 道区画の旧地権者にも、高齢・無職・自己資金不足や身寄りがない 旧地権者にも、転入して取得予定の新地権者に対しても、十分に還 元される事業方式でなければならない。本研究では、このような事 業特性を利益性と呼ぶ。このような利益性を満足できれば、交涉や 合意形成等も進みや寸く、建替え後の入居の確実性が高まる。利益 性が、公的助成や容積率緩和策なしに確保されれば、自治体の負担

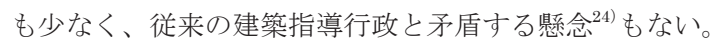

\section{4. 共同建替えの業方式の諸類型と適合性}

共同建替えの事業方式は、事業主体の位置づけ、外部専門職能の 関与の有無により、(1) 分譲方式、(2-1) 自力型組合方式及び $(2-2)$ 委託型組合方式の 3 方式を想定することができる。以下、この 3 方 式の特性を検討し、前節で触れた共同建替え事業の小規模性・非整 形性・利益性の 3 条件に照らし合わせる。

\section{(1) 分譲方式}

不動産開発事業者が事業主体となり、建替え前の不動産を取得（買 収）し、保留床分を建替え後に分譲して収益を得る方式である。再 入居する地権者については権利変換を行うこととなる。

分譲方式は見込生産であり、不動産開発事業者には開発利益と売 れ残りリスクが生じる。売れ残りリスクに見合う開発利益確保のた め、設計・施工を標準化注4) し設計料を抑えるのが一般的である。あ るマンション分譲大手元担当者へのヒアリングによると、分譲方式 の場合、設計料を工事費の $2 \sim 3 \%$ 程度、工事費を 20 万円 $/ \mathrm{m}^{2}$ 前後 以下として原価率を $60 \sim 70 \%$ に抑え、売れ残りリスクを最小化す るため宣伝・広告費 $(3,000$ 万円以上)、販売人員関係費 $(4,000$ 万 円以上)、モデルルーム費（3,000 万円以上）が費やされる。標準化 設計・施工のため、 $1,000 \mathrm{~m}^{2}$ 以上の接道条件の良い整形地を対象とし、 規模の経済性の確保のため事業規模 10 億円以上となるのが一般的 で、大規模な整形地での容積率を最大限に生かした標準プランの計 画が優先される。こうした事業特性は、（i）小規模性や（ii）非整 形性といった条件にそぐわない。（iii）利益性についても、標準的な 建築計画が当てはまらない敷地では事業採算性を確保しにくい。こ のため、大幅な容積緩和や公的助成、地価上昇期待等が伴わなけれ ば成立し難いと考えられる。

\section{(2) 組合方式}

組合方式とは、建設組合（従前地権者を主体とする入居予定者で 設立）が事業主体となり、設計・施工等の建替事業の計画・運営役 
務を直接発注するコーポラティブ方式 (building co-operatives) の ことである。本研究では、このうち、設計、施工、契約・登記手続 といった役務は専門職能に委託するものの、事業の計画・運営やそ れに係る調整や意思決定は、外部専門家の支援を一切受けずに組合 がすべて自力で行う方式を自力型組合方式と呼ぶ。これに対し、事 業の計画・運営やそれに係る調整や意思決定一の支援業務を外部専 門家に委託する方式を委託型組合方式と呼ぶ。

\section{(2-1) 自力型組合方式}

地権者主体の組合は、住環境への好みやコミュニティ意識を共有 しやすく、プライバシーへの配慮も限定的で済むため、小規模非整 形地で開放性のある計画を推進するのにも適している。こうした事 業特性は、（ｉ）小規模性、（ii）非整形性を満足する。（iii）利益性 については、区画統合・土地有効活用等による開発利益を全て組合 が得るため、分譲方式及び委託型組合方式よりも有利である。しか し事業の計画・運営を自力で行うため、建替え前の区画の土地代評価、 建替え後の取得予定住戸の位置取りや值付け等、組合員相互の利害 が反する場面で調整が難航し事業が長期化・中断する不確実性が伴 う懸念がある。外部からの新規入居予定者の募集に際し、計画等の 説明が不十分で、入居予定者が確保できない状況に陥る恐れもある。

\section{(2-2) 委託型組合方式}

委託型組合方式は、外部の専門家（組合運営支援業者）が建築家 と協働して専門能力を生かし、事業計画、土地価格查定・取得、設計・ 予算案等の調整を客観的・中立的な立場で行う。開発利益は基本的 には事業主体である組合に帰属するものの、組合運営支援業者に委 託業務の手数料を支払うため、自力型組合方式より若干利益性は劣 る。

この方式は自力型と同様に、（i ）小規模性、（ii）非整形性といっ た条件を満たす。実際に、こうした組合から運営業務を受託する業 者が、都心周辺部の小規模非整形地で平均 7.6 戸規模 (全 95 棟) のコー

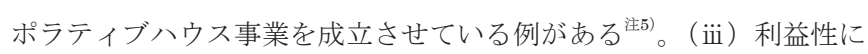
ついても、客観中立的かつ専門的な建替え媒介業者が介在すること で、特定の組合員の利害に左右されずに組合内の利害を調整し、専 門的な説明能力によって外部からの新規入居予定者の募集等を順調 に進めて事業の不確実性を抑えられる。組合には委託業務料負担が 発生するが、これを総事業費に対する一定の料率として定め、分譲 方式における開発者利益の $1 / 3$ 程度に抑えるものとする注6)

以上の考察を踏まえ、延焼過程ネットワークのハブを選択的に不 燃化する目的で、木造密集地域における小規模・非整形の区画群を 対象とする共同建替えに適合する事業方式を比較する（表 1 )。

まず、分譲方式が適合しないのはこれまでの考察から明らかであ る。次に組合方式のうち委託型組合方式は、自力型組合方式よりも 利益性で若干不利な面があるものの、この方式で利益性が成り立つ ならば、専門家の組合運営支援によって確実性が見込まれる。した がって本研究では委託型組合方式をより有利な事業方式と考え、木 造密集地域内に実在する区画群を対象モデルとした共同建替え事業 の詳細なシミュレーションによって利益性を評価する。

\section{5. 利益性詳細評価}

この委託型組合方式を前提として、木造密集地域内に実在する区 画群を対象モデルとした共同建替え事業のシミュレーションを行う。
表 1 事業方式類型と共同建替えへの適合性 （灰色は適合性に問題がある部分）

\begin{tabular}{|c|c|c|c|}
\hline & \multirow{2}{*}{ 分譲方式 } & \multicolumn{2}{|c|}{ 組合方式 } \\
\hline & & 自力型 & 委託型 \\
\hline 事業主体 & 不動産開発事業者 & 入居予定者から成る建設組合 & 入居予定者から成る建設組合 \\
\hline 運営䒠務 & 不動产開発事業者 & 入居予定者からら成る建設組合 & 組合運営支㗭業者 \\
\hline 事業特性 & 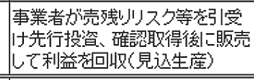 & 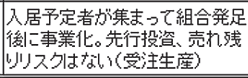 & 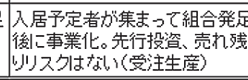 \\
\hline 確寒性 & $\begin{array}{l}\text { 地権者は土地韵売却すれば、不 } \\
\text { |動産開発事業者が事業化 }\end{array}$ & 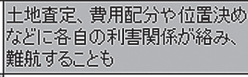 & 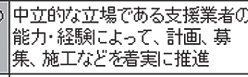 \\
\hline 小規模性 & $\begin{array}{l}\text { 販売费用等孛捻出するにには、販 } \\
\text { 壳戸数50户以上がー般的 }\end{array}$ & 5戸前後でも事業化可能 & 5戸前後でも事業化可能 \\
\hline 非整形性 & 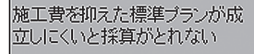 & $\begin{array}{l}\text { 非整形地でも建篓家の設計上の } \\
\text { 工夫で対吣可能 }\end{array}$ & $\begin{array}{l}\text { 非整形地でも建筑家の設計上 } \\
\text { 夫で就念可能 }\end{array}$ \\
\hline $\begin{array}{l}\text { 地権者の利 } \\
\text { 益性 }\end{array}$ & 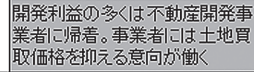 & $\begin{array}{l}\text { 開発利益の全ては地権者ないい } \\
\text { 組合にし带禹 }\end{array}$ & 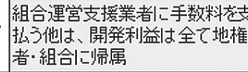 \\
\hline
\end{tabular}

（1）シミュレーション対象区画の設定 (1)シミュレーション対象区画の条件

対象モデルは、共同建替えの必要性が高いにもかかわらず、共同 建替えが最も難しいと想定される箇所を選ぶ。具体的には、次の（a） 〜 (d) の条件を同時に満たす箇所とする。

（a）延焼拡大の危険性（不燃化の必要性）

延焼拡大の危険性を抑止するために、不燃化を優先す心゙き区画を 共同建替え事業の対象区画群に含めることを条件とする。この不燃 化を優先すべき区画は、木造家屋群の密集度（単位面積当たりの木 造家屋棟数）が高い特別区における防災街区整備地区内から、延焼 過程ネットワーク（図 1 左）におけるハブ（当該建物から延焼限界 距離内に位置する隣接木造建物が 6 棟以上ある木造建物：図 1 右、 図 6 の $\mathrm{E}$ 区画はこれに該当）に当たる。
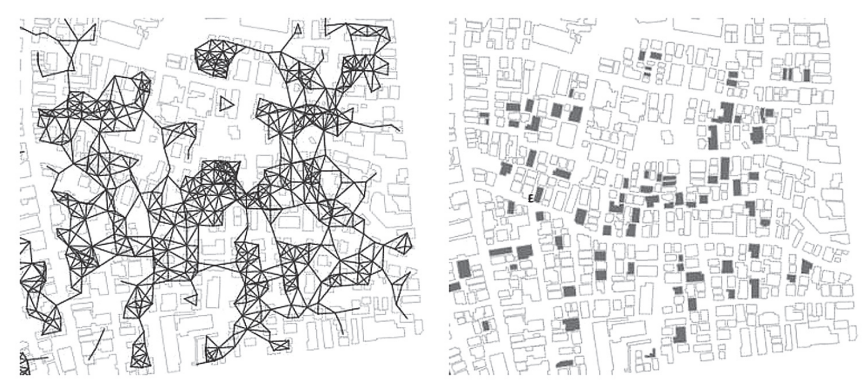

図 1 延焼過程ネットワークとハブ（中野区南台 2 丁目部分）

（b）工事車両の通行困難（共同建替えの必要性）

幅員 $2.25 \mathrm{~m}$ 未満の道路は一般的な工事車両にとって物理的に通行 困難である永7)。対象区画群としては、幹線道路に至る通路上にこう した险路があり、险路手前で工事車両が通行可能な近傍区画まで区 画統合する必要がある区画を含める。この際、幅員 $4 \mathrm{~m}$ 未満の通路は、 建築基準法第 42 条第 2 項の適用を受けるものとする。

東京都木造住宅密集地域整備事業の実施箇所である 46 地区（約 2,050 ha）において、5 区画以下の統合では建替えが可能とならない 区画群をゼンリン住宅地図において全数確認した結果、38 箇所 181 棟が該当した。こうした区画群は、二項道路にも認定されない幅員 
$1.8 \mathrm{~m}$ 未満の通路に囲まれた「通路包囲地」 12 か所 96 棟（図 2 左） ないし、5 区画以下の統合では险路を経ずに幹線道路まで通行可能と ならない「街区梁奥地」 26 か所 85 棟（図 2 右）に大別される。こ の 46 地区（約 2,050 ha）内の住宅棟数密度を 60 棟/ha（国土交通 省の密集市街地の定義）とすると同地区内住宅棟数は 123 千棟と推 計されるが、前述の 181 棟は同地区内住宅総数の約 $0.15 \%$ に過ぎず、 ごく少数の例外を除けば、都区部の木造密集市街地では最大 5 区画 を統合すれば共同建替えが可能になると見ることが出来る。これを 踏まえ、統合区画数については、5 区画の統合が必要な区画群をシミュ レーション対象とし、5 区画統合の事例の中で、小規模・非整形のた め共同建替えが最も難しい区画群をシミュレーション対象として設 定する。

（c）小規模性（3.（i ）に同じ）

統合後の敷地面積が約 150 〜 $500 \mathrm{~m}^{2}$ の範囲にある区画群を対象と する。この規模を下回る場合は一戸建て建築用地としての利用、こ の規模を上回る場合は分譲マンション用地や位置指定道路を築造し た宅地分譲用地としての利用、が優位になると考えられる。

（d）非整形性（3.（ii）に同じ)

統合後もなお外周部に凸凹の多い非整形地となる区画群を選ぶ。 標準的で費用効率の高い共同住宅プランが成立しづらい困難な条件 下でも十分な事業性が確保されることを検証するためである。

\section{(2)具体的なシミュレーション対象区画の抽出}

以上の条件に基づき、まず（a）延焼拡大の危険性の観点から、都 内 23 区の中から中野区に着目した。中野区は豊島区とともに木造家 屋群の密集度が高く、細街路に面する住宅の比率が最も多いため、 都内では最も延焼危険性が高い区と見ることができる（図 3）。

次に、中野区の防災整備地区 2 地区のうち重点整備地区に指定さ れている南台 $1 \cdot 2$ 丁目に着目し、その中でも統合が不可欠な接道不 良区画群が密集して存在する南台 2 丁目内の街区（番地単位）に対 象地域を絞り込んだ。図 4 は、抽出された接道不良区画群（枠線内 区画群、黒色部分を除く色）とこれらに隣接する接道条件に問題の ない区画（黒色）からなる区画群（枠線内）を示す。この街区では、 幅員 $1.5 \mathrm{~m}$ 未満の通路（工事車両も通行できず二項道路の適用も受 けられない幅員）にのみ面し、単独再建築が不可能な区画群 12 箇所 が約 $18 \mathrm{~m}$ に亘り連続する。統合後の区画群の面積は $150 \sim 500 \mathrm{~m}^{2}$ である。

これらの 12 箇所の区画群は、いずれも最大 5 区画を統合すれば奥 側の接道不良区画まで共同建替えが可能となっている。これらの区 画群から、敷地統合後の非整形性 ${ }^{\text {住10) }}$ が最も高い箇所（図 4 の左下枠 線内の番号 3 の 5 区画（平均築年数 40 年、合計敷地面積 $438 \mathrm{~m}^{2}$ 、 第一種中高層住居専用地域、建蔽率 $60 \%$ ・容積率 $200 \%$ ）をシミュレー ション対象として抽出した。接道不良区画ほど統合による差益は大 きくなるので、共同建替えの事業性は統合前後の土地評価額 ${ }^{{ }^{\ddagger}}{ }^{11}$ に左 右されるが、モデル区画群の敷地統合前後の基準地価に対する土地 価格割合（図 5 の縦軸）は統合前 $36.3 \%$ ・統合後 $57.0 \%$ で、候補区 画群 12 箇所の統合前平均 $37.1 \%$ ・統合後平均 $57.9 \%$ に照らし、こ の地区での代表性に問題はない。

\section{（2）建替え計画の設定}

以上の選定過程を経て抽出された対象箇所について、シミュレー ションの前提となる共同建替えの基本計画案を作成する。
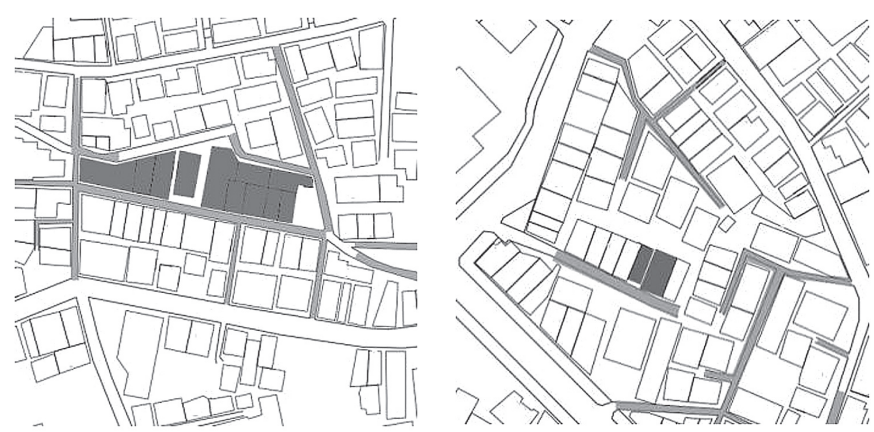

図 2 通路包囲地 (左) ${ }^{\text {注10) }}$ と街区深奥地 (右) $)^{\text {注11) }}$ (濃灰色が共同建替え困難区画、薄灰色は幅員 $2.25 \mathrm{~m}$ 未満の道路)

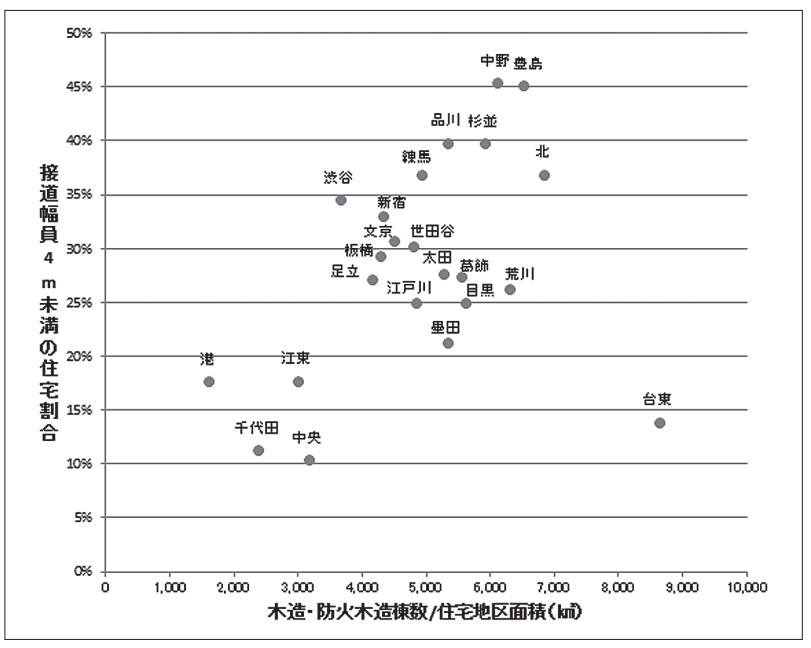

図 3 木造密集度と細街路比率（東京 23 区）

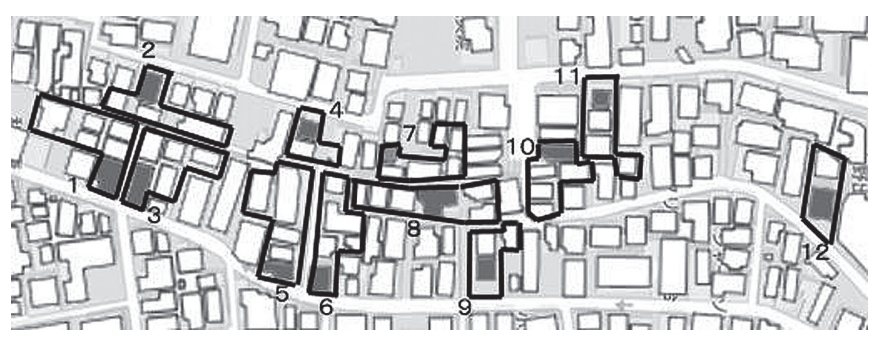

図 4 中野区南台 2 丁目の区画統合想定箇所（抽出箇所；番号 3) (濃色部分が延焼危険建物、枠線内が統合対象区画群)

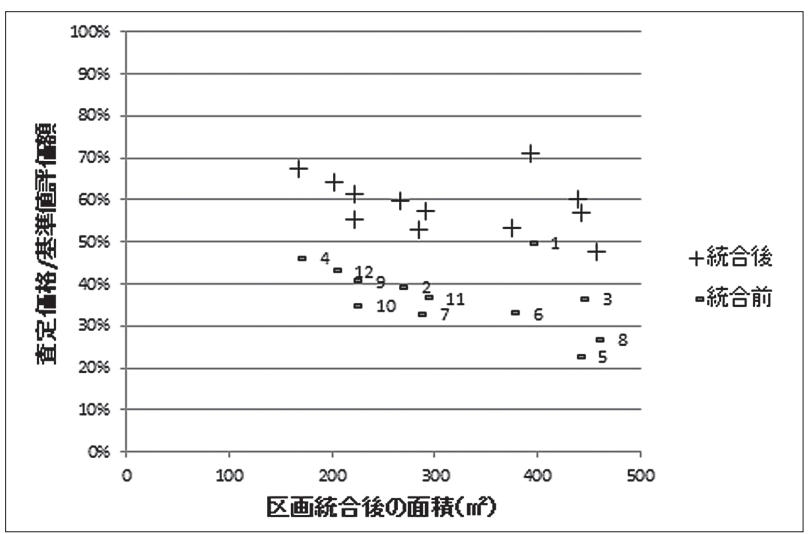

図 5 統合後の面積・対基準地価評価の割合 (南台 2 丁目 計画地は番号 3) 
現況及び建替え計画注 ${ }^{122}$ を、図 6 に示す。建替え対象となる 5 区画 $(\mathrm{A} \sim \mathrm{E})$ の敷地合計面積 $438 \mathrm{~m}^{2}$ を区画統合し、街並みに合った低 層連棟式住宅 $(\mathrm{RC} \text { 造・ 区分所有 })^{25)}$ に建替える。建替え前の接道条 件は、 $\mathrm{A} \cdot \mathrm{B} \cdot \mathrm{D}$ 幅員 $1.5 \mathrm{~m} 、 \mathrm{C}$ 幅員 $1.0 \mathrm{~m}$ であり、 $\mathrm{E}$ 以外は無道路 地に該当する。この対象モデルについて、以下のアからカの条件に より建替え事業費用や資金計画等を試算した。

ア．従前の土地（5区画）を組合が買上げて統合し、建替え（全 7 戸） を進める。なお、接道区画は道路後退によって面積は $19 \%$ 減る。地 権者は従前の家屋と同等の床面積分の住戸を取得し、残余の 2 戸は 外部の新規入居予定者が組合に参加して取得する。

イ。一帯の地域に調和した低層分棟式の建替え計画とする。軒高を 3 層（10 m）に抑え、建坪 $744.6 \mathrm{~m}^{2}$ 、指定容積率 $200 \%$ に対して使用 容積率 $170 \%$ とした。低層建物に適した壁式構造の鉄筋コンクリー 卜造を採用し、工事費 27.2 万円 $/ \mathrm{m}^{2}$ と税・諸経費 11.0 万円 $/ \mathrm{m}^{2}$ を見 込む（標準的なラーメン構造の分譲マンションでは、工事費は 17.7 万円 $/ \mathrm{m}^{2}$ 程度と想定する) $)^{\text {ì } 13)}$ 。

ウ. 従前/従後の居住性の違いは、戸建て/RC 造アパートの帰属家 賃として貨幣価值の差に反映させる。例えば、専有面積 $61.2 \mathrm{~m}^{2}$ と した場合、現時点の帰属家賃は、 $\mathrm{RC}$ 造アパートでは 193 千円/月、 築 40 年の木造戸建てでは 126 千円/月となる注14)。これらの 15 年分 の現在価值を割引率 $0.8 \%$ で求めた。
エ. 試算ケースでは、従前の地権者には自己資金や所得がなく、リバー ス・モーゲージ方式で建替え資金を調達するものと想定する衤15)。具 体的には、建替え後の土地・建物を担保とし、担保価值の 7 割を極 度額として金融機関が融資する。期中利払いはせず融資残高に加算 され、融資期間満了時（所有者死亡を含む）には金融機関が担保物 件を売却して元利を回収する。融資期間 15 年、借入金利 $0.8 \%$ とする。 これにより、建替え事業期間および 15 年間の居住期間に、組合及び 全ての入居予定者の資金繰りを確保する。

才．現有不動産の買い上げに用いる評価額は、従前の各地権者に公 平になるように、個々の不動産から生じる想定利益の現在価值 (NPV:

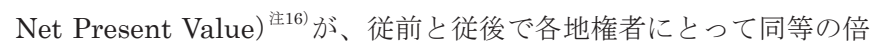
率になるように調整する。この「NPV 倍率」は、共同建替えした場 合の当該不動産（土地・建物）の期末純資産額、期間中帰属家顀及 び期中累積純収益の現在価值と、木造戸建てのまま建替えない場合 の現在価值の比をとる。

カ. 期間中の物価や地価の変動は簡単化のため考慮対象外とし、建

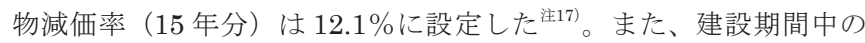
仮移転費用や税負担あるいは公的助成等については、簡単化のため 省略する。

\section{(3) 試算結果}

以上の前提にもとづいて、建替え事業に要する費用や資金計画等

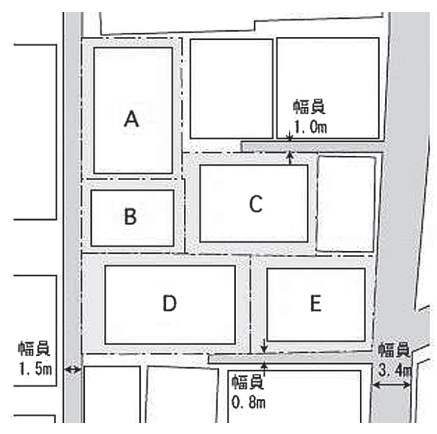

現状

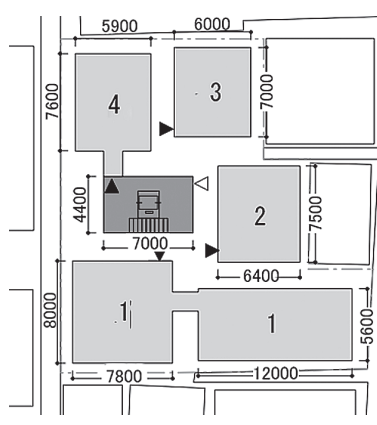

建替え後 1 階

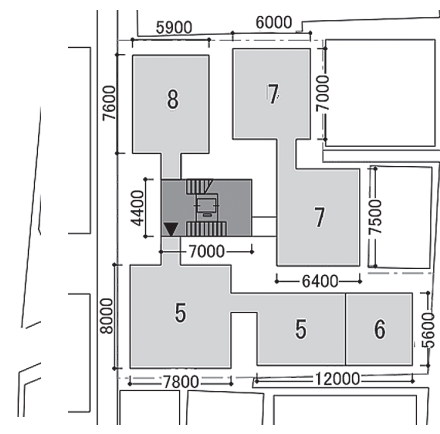

建替え後 2 階

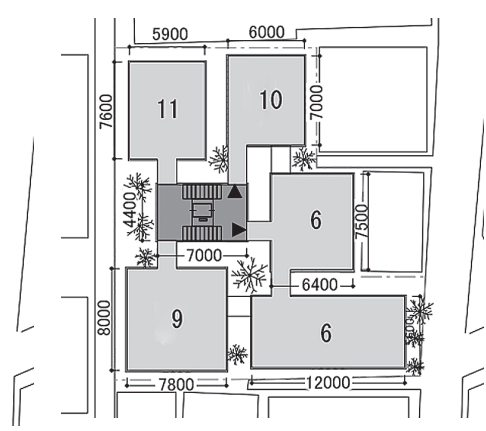

建替え後 3 階

図 6 シミュレーション対象区画群の現状（左）および建替え計画（濃灰色は階段室）

表 2 地権者 $A \sim E$ 〜 ついての現状・現状維持 ・共同建替え実施の現在価値比較

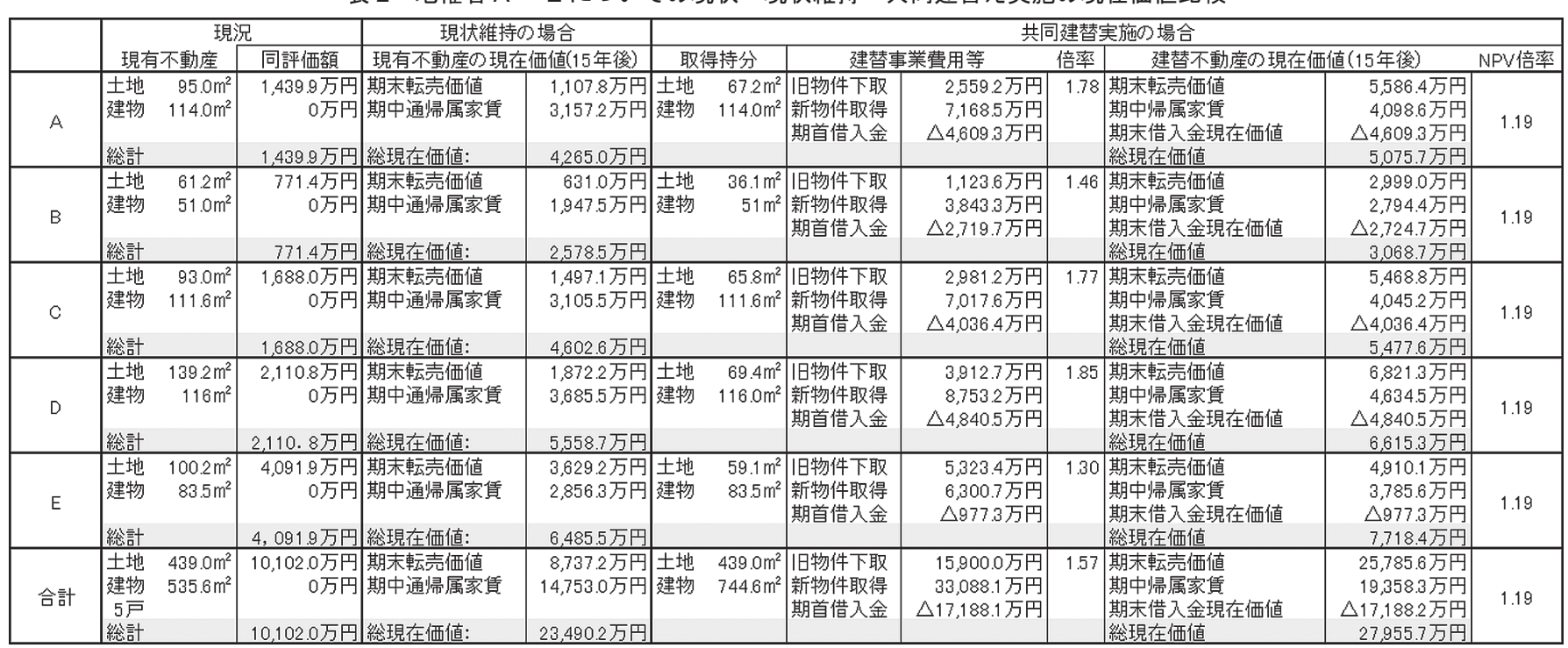


を試算した結果を表 2 に示す。共同建替えを実施した 15 年後の純資 産額 (=期末転売価值一期末借入金残高) はいずれもプラスで、リバー ス・モーゲージ方式が成立することが確認できる。この純資産額は、 建替えない場合の土地価格 (期末転売価値) と比較しても遜色はない。 居心地が良く防災性に優れた居住性が帰属家賃（各地権者とも約 1,000 万円分向上）に反映され、NPV 倍率は 1.19 倍となり、現状維 持の場合よりも資産価值が上回る試算結果が得られた。

事業全体の採算性は、区画統合による資産評価益が大きく貢献す る結果、各地権者に十分な便益（NPV 倍率＝1.19 倍）が生じた。 区画統合によって奥側の接道不良区画（A，B，C，D）も建築可能 となり、これらの買上げ価格は現状に比べて 46 ～85\%向上する。 接道条件の良い接道区画（E）は、単独建替えの場合には道路後退が 義務づけられて土地価格が下がる。一方、共同建替えに参画すれば、 接道不良区画の接道条件の改善に貢献するため、全体の NPV 倍率が 適用されて、現有不動産の評価額 (4,092 万円) は共同建替え後は 5,323 万円（3 割増）に増価する。接道側区画は共同建替えによって、接道 不良区画側からの延焼による被害も免れる。

このように、「単独では建替え困難な区画を多く含むほど、共同建 替え事業が有利になる」「接道区画も共同建替えへの参画によってメ リットが生じる」という共同建替えに適した事業構造が認められる。

外部からの新たな入居予定者にとっても、住宅取得コストの優位 性がある。区画統合後も非整形地であるため土地評価額が基準地価 の 6 割に抑えられ、委託型組合方式のため分譲方式に比べ専門業者 への支払いが 3 分の 1 になるために、分譲方式よりも設計料や工事 費が上昇する費用増を十分に補える費用減が発生する。本方式によ る住戸の取得費用は 200 万円/坪で、周辺の分譲マンションの販売 価格（250 万円/坪前後）に対し 2 割ほどのコス卜優位性がある。分 譲方式に比べ空間の豊かさもあるため、新たな入居予定者の募集も しやすく、組合設立の実現可能性は高まる。

(4) 応用スキーム

さらに、この建替え計画の応用スキームを考案することで、住宅 取得、資金計画および居住空間に関する地権者の様々な意向により 柔軟に対応する選択肢を用意することもできる。ここではそうした 選択肢の例として、ア．親子二世代で居住して住宅ローンを返済し て子世代に資産を残寸方法、イ、建替え後に一部を貸貸して返済資 金に充当する方法、ウ. 一切の債務を負わずに取得・居住する方法、 の事業性を検証する。

ア. 二世代型 : 従前と同等の専有面積の住戸を取得するために、親 世帯の土地売却所得と子世帯の給与所得を収入合算し、親子世帯の 共有財産として二世代型住宅ローンを組んで、期中に利息を支払う ことも可能である。リバース・モーゲージによる期末一括返済に比 べて期中の金利負担を抑えるため、帰属家賃相当を毎月返済額に充 てたとすると、区画 $\mathrm{C}$ の地権者が従前と同等の広さの住戸を取得し た場合では金利 $0.8 \%$ 、元利均等払いで 15 年後の残債は 1,362 万円 となり、22 年後には完済することができる。

イ.一部賃貸:建替え後の住戸の一部 (2 階部分等) を貨貸住戸とし、 賃料収入を返済資金に充当することも可能である。高齢で階段の昇 降を避けて従来から 2 階を殆じ利用していなければ、この設定は現 実的である。区画 $\mathrm{C}$ の地権者が取得する住戸の一部に賃貸部分を設 定した場合、新築 $\mathrm{RC}$ 造になるため賃貸市場でも高く評価され、月
額賃料収入は 16.9 万円 (年間 203 万円) 、 15 年間の総賃料収入は 3,045 万円となる。これを返済資金に充当寸れば、15 年後の借入金残高は 967 万円に縮小寸る。15 年後の資産評価額は 6,176 万円、純資産額 は 5,028 万円となるので、子世帯が借入金残高を清算して相続し、 居住することも可能である。

ウ．無借金 地権者が一切の債務を負うことを敬遠する場合には床 面積を縮小した建替え計画も用意できる。区画 Cでは、統合前の土 地評価額は 1,688 万円だが、買い上げ額は区画統合効果により 2,981 万円となる。これを建替え後の物件取得費用に充てれば、借入ゼ口 でも専有面積 $47.5 \mathrm{~m}^{2}$ の住戸を得ることが可能で、 15 年後の資産価 值として 2,323 万円（建替えない場合では 1,497 万円）を享受できる。 床面積は従前の $111.62 \mathrm{~m}^{2}$ の半分以下になるが、高齢等で 2 階部分 を活用していない場合は、階段分を除いた実質の居住面積は大きく は変わらないため、現実的な選択肢になりうる。

\section{6. 本方式の一般的な成立可能性の検証}

次に、この事業方式 (委託型組合方式、リバース・モーゲージ、 低層分棟型）が木造密集地域における共同建替え事業対象区画群に ついて広範に成立するための条件を導く。今回の試算では、事業性 のポイントは、(1)区画統合による接道不良区画群の土地増価が NPV 向上の源泉となること、(2)統合後も非整形地で土地評価の減価額が 大きいため分譲方式に対しコスト優位性があること、にある。この ような事業性は、事業箇所に応じた土地評価額特性により变化する ことに着目して事業性の必要条件をモデル式化し、一般的な成立可 能性を検証する。

統合前の区画 $\mathrm{k}$ における「敷地面積」「専有部分の使用容積率」「単 位床面積当たりの帰属家貨」「基準地価 $\mathrm{p}$ に対する土地減価率」を $\mathrm{S}_{\mathrm{k}} 、 \mathrm{v}_{\mathrm{w}} 、 \mathrm{r}_{\mathrm{wk}} 、 \mathrm{~d}_{\mathrm{k}}$ と、統合後の区画に係る「敷地面積」「専有部分の 使用容積率」「単位床面積当たりの帰属家賃」「基準地価 $\mathrm{p}$ に対する 土地減価率」を $\mathrm{S}_{\mathrm{u}} 、 \mathrm{v}_{\mathrm{u}} 、 \mathrm{ruk}_{\mathrm{u}} 、 \mathrm{~d} \mathrm{u}$ とおく。本方式 (不整形地に適した 壁式 $\mathrm{RC}$ 造を使用）の「単位床面積当たりの工事費」は $\mathrm{c} 、$ 分譲マン ション方式（整形地向けのラーメン構造）は $\mathrm{c}_{\mathrm{r}}$ とする（一般に $\mathrm{c}>$ $\mathrm{c}_{\mathrm{r}}$ ）。「原価率」を組合方式では $\mathrm{g}_{\mathrm{c}}$ 、分譲方式では $\mathrm{g}_{\mathrm{d}} 、 「$ 現在価值割引

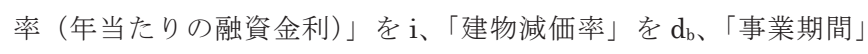
を $\mathrm{t}$ とする。

\section{（1）共同建替えに係る NPV 倍率>1}

共同建替え成立の第一の条件は、共同建替えをする場合と現状維 持の場合に得られる現在価值額の比率である NPV 倍率 $(\mathrm{mNPV})$ が 1 を上回ることであり、次式で表現される。

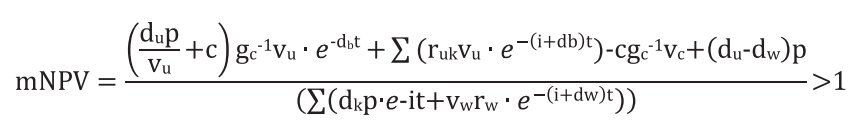

分母は建替えない場合の NPV で、第 1 項・第 2 項は残存不動産分 と期中帰属家賃分に相当する。分子は建替え後の NPV で、第 $1 \sim 4$ 項は期末不動産価値、期中帰属家賃、期末債務残高、敷地統合によ る土地増価に相当する。分母・分子とも土地 $1 \mathrm{~m}^{2}$ 当たり価値に換算し、 建物分は容積率を用い土地 $1 \mathrm{~m}^{2}$ 当たり価值に換算している。

この式について、5.（2）のシミュレーションで用いた值として、 木造二階建てを想定した建蔽率 $60 \%$ 、使用容積率 $120 \%$ 、さらに近 年の傾向值として在来木造の再建築工事費 203 千円 $/ \mathrm{m}^{2}$ （総費用の 
うち $73 \%) 、 \mathrm{v}_{\mathrm{u}}=170 \% 、 \mathrm{c}=272$ 千円 $/ \mathrm{m}^{2} 、 \mathrm{~d}_{\mathrm{b}}=0.86 \% /$ 年、 $\mathrm{t}=$ 15 年、 $\mathrm{r}_{\mathrm{u}}=1,740$ 円 $/ \mathrm{m}^{2} \cdot$ 月、 $\mathrm{i}=0.8 \%$ を当てはめ、この不等式を 基準地価及び対象敷地の土地減価率を説明変数として次式のように 単純化できる。

$$
\mathrm{d}_{\mathrm{w}} \leq\left\{(60 \mathrm{p}+46,240) \mathrm{e}^{-0.129+56.59 \mathrm{p}-16,634\} / 173.91 \mathrm{p}}\right.
$$

この不等式が成り立つ領域は図 7 の曲線の下側に相当し、統合区 画前の基準地価 $\mathrm{p}$ に対する土地減価率 $\mathrm{d}_{\mathrm{w}}$ が、基準地価 $\mathrm{p}$ の絶対水準 に応じて定まる一定水準以下であることを意味する。また、リバース・ モーゲージの成立条件は、次式のように 15 年後の不動産の期末価值 （左辺）が期末債務残高（右辺）を上回ることと表現できるが、これ はこの $\mathrm{mNPV}>1$ の条件式が満足されれば、おのずから成立する。

$$
\begin{aligned}
\left(\frac{\mathrm{d}_{\mathrm{up}}}{\mathrm{v}_{\mathrm{u}}}+\mathrm{c}\right) \mathrm{g}_{\mathrm{c}}{ }^{-1} \mathrm{~V}_{\mathrm{u}} S_{\mathrm{k}} e^{-\mathrm{dbt}} & \\
& >\operatorname{mNPV}\left(\mathrm{d}_{\mathrm{k}} \mathrm{p}+\mathrm{v}_{\mathrm{w}} \mathrm{r}_{\mathrm{w}} e^{-(\mathrm{i}+\mathrm{d} w) \mathrm{t}}\right) S_{\mathrm{k}}-\mathrm{r}_{\mathrm{u}} e^{-(\mathrm{i}+\mathrm{db}) \mathrm{t}} \mathrm{v}_{\mathrm{u}} S_{\mathrm{k}} \\
& -\mathrm{d}_{\mathrm{u}} S_{\mathrm{k}}
\end{aligned}
$$

\section{（2）分譲マンション方式に対するコスト優位性}

第二の条件は、分譲マンション方式に対するコスト優位性（ここ では 2 割安とおく) であり、その条件は、

\section{$\left(\mathrm{d}_{\mathrm{u}} \mathrm{p}+\mathrm{cv}\right) \mathrm{g}_{\mathrm{c}}{ }^{-1} \leq 0.8 *\left(\mathrm{p}+\mathrm{c}_{\mathrm{r}}\right) \mathrm{g}_{\mathrm{d}}{ }^{-1}$}

となる。左辺は組合方式の場合の取得費用、右辺は周辺の幹線道路 沿いに計画される分譲マンションの取得価格の $80 \%$ を示す。いずれ も専有面積 $1 \mathrm{~m}^{2}$ 当たりに換算している。

専有部分の使用容積率は、本試算ケースでは両方式とも $170 \%$ で ある。分譲マンションでは建築面積に共用部分を含めるために、組 合方式による計画（図 6）並みに使用容積率をとるのは難しいが、保 守的に同等の $170 \%$ を確保すると仮定した。p 以外について 5. (2) のシミュレーションで用いた近年の傾向值を代入すると、

$(0.6 \mathrm{p}+1.7 * 272) * 1.3 \leq 0.8 *(\mathrm{p}+1.7 * 181) * 1.5$

$$
\therefore \mathrm{p} \geq 551
$$

と、基準地価を説明変数とする式に単純化され、基準地価 551 千円 / $\mathrm{m}^{2}$ 以上といった条件に整理できる。小規模不整形地での壁式 RC 造 は、地価が一定水準以上の箇所であれば、大規模整形地でのラーメ ン構造建築に対するコスト劣位性を克服できることを示している。

試算対象地の建蔽率・容積率は $60 \%$ ・ $200 \%$ であったが、都区部 の木造密集地域の典型像として建蔽率・容積率 $60 \% \cdot 150 \%$ 、使用 容積率 $120 \%$ を念頭においてこの式を補正すると、 $\mathrm{p} \geq 487$ すなわち 基準地価 487 千円 $/ \mathrm{m}^{2}$ 以上との条件が導かれる。

都区部の木造密集地域は都心から概ね $10 \mathrm{~km}$ 前後の圈内に位置す るが、東京駅からの距離圈別平均地価（平成 24 年基準地価）は、 $5 \mathrm{~km}$ 未満 1,063 千円 $/ \mathrm{m}^{2} 、 5 \mathrm{~km}$ 以上 $10 \mathrm{~km}$ 未満 539 千円 $/ \mathrm{m}^{2}$ であり、 この条件は概ね満たす。

\section{（3）委託組合型共同建替え事業の成立条件のまとめ}

このように委託組合型共同建替え事業の成立条件は、(1) 統合前 区画の「基準地価 $\mathrm{p}$ に対する土地減価率」が一定水準以下、(2) 事 業実施区域における地価水準が一定水準以上、の 2 点に要約される。 本試算ケースを想定すると、（1）及び（2）はそれぞれ、

$$
\begin{gathered}
\mathrm{d}_{\mathrm{w}} \leq\left\{(60 \mathrm{p}+46,240) \mathrm{e}^{-0.129+56.59 \mathrm{p}-16,634\} / 173.91 \mathrm{p}}\right. \\
\mathrm{p} \geq 551
\end{gathered}
$$

となり、図 7 の 2 本の線の右下象限内に対応寸る。たとえば基準地 価が 650 千円 $/ \mathrm{m}^{2}$ のときは、接道側（幅員後退で $19 \%$ 減価）の区画
数 1 に対し、接道不良区画（各 $75 \%$ 減価） 4 以上であれば成り立つ。 接道側区画の面積が、区条例の定める最低敷地面積（目黒区・世田 谷区では建蔽率 $60 \%$ の場合 $70 \mathrm{~m}^{2}$ ) を下回り、その減価率が $70 \%$ な らば、接道不良の区画数がいくつあっても成り立つこととなる。

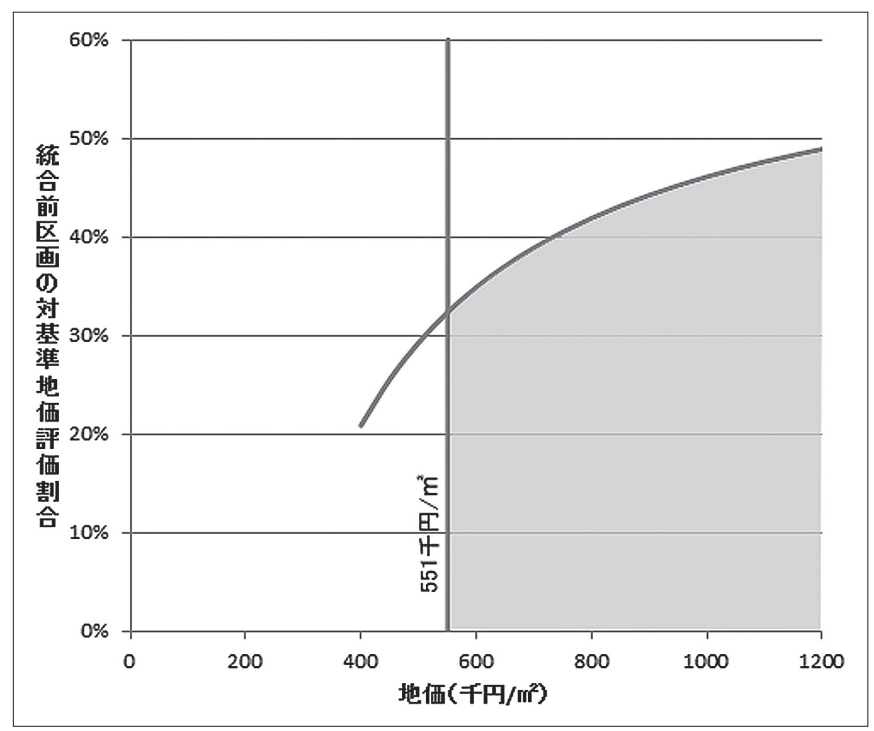

図 7 委託組合型共同建替え事業の成立条件 (灰色部分が事業成立可能領域)

\section{7. まとめ}

木造密集地域の大規模火災の抑止には、延焼過程ネットワークの 八ブに相当する延焼危険建物群を選択的に不燃化することが効果的 である。こうした延焼危険建物群は、街区内奥に位置して、再建築 に必要な法規面・施工面の接道条件を満たさないことが多い。こう した建物群を不燃化するためには、接道不良区画を含めて数区画を 統合し、統合後も小規模・非整形な敷地において各地権者に十分に 利益が生じるような共同建替え事業を行う必要がある。

分譲方式では小規模性や非整形性といった条件にそぐわないが、 委託型組合方式はこうした事業の条件に適い、都内の木造密集市街 地を対象とした試算でも、対象区画の地権者全ての便益を向上させ ることが判明した。また建替え後も担保価值が維持されるためにリ バース・モーゲージの活用も可能であり、無職・自己資金不足といっ た地権者も共同建替え事業に参加することができる。こうした要因 は主に、区画統合によって接道不良区画が建築可能になって資産差 益を生むこと、統合後も非整形地であるため基準地価から減価され ることであり、いままでは建替え困難とされた区画群への適用によ り適している。そして本方式が一般的に成立する条件は、対象地域 の基準地価が約 500 千円 $/ \mathrm{m}^{2}$ 以上と算出される。試算前提の傾向值 が当てはまれば、この地価水淮は都内の木造密集地域の大半が該当 し、本方式の広範な有効性が確認される。

しかし、各地権者が共同建替え事業が有利であると理解していて も、その交渉を主導したときの心理的・経済的な負担、計画見通し の不確実性、交涉不調時の近隣関係の不和などを懸念し、実際には 協力関係に至らない事態が想定される。そのような事態を解消寸る ための公的介入等の施策 ${ }^{26)}$ を別途検討寸る必要がある。 


\section{参考文献}

1）加藤孝明：延焼シミュレーションによる防災まちづくり施策の代替案評価 の試み, 総合都市研究 (75), 71-78, 2001-09 東京都立大学都市研究所

2）織山和久, 小滝晃 : 延焼過程ネットワークのスケールフリー性に着目した 木造密集地域における延焼危険建物の選択的除去効果の実証, 日本建築学会 環境系論文集第 80 巻，第 711 号，pp.389-396, 2015.5

3）山崎福寿：木造住宅密集地域の再開発が進まない基本的原因とその解決策 について, 都市住宅学 83 号, pp.46-51, 2013.10

4）高木和歌子、大村謙二郎：密集市街地居住者の建替え選好意識に関する分 析, 都市住宅学 35 号, pp.99-104, 2001.10

5）真野洋介、武田友佑、小林愛佳、佐藤滋 : 墨田区一寺言問地区における市 街地更新、住宅供給実態と地域内の住み替えの関係性，日本都市計画学会都 市計画論文集第 38 巻第 3 号, 2003.10

6）文京区都市計画部：根津駅周辺まちづくりアンケート調査報告書, 2006.3

7）原田陽子：大阪市空堀地区における路地単位特性と接道不良長屋所有者の 居住改善実態, 日本都市計画学会都市計画論文集第 76 巻第 669 号, pp.2117-2126, 2011.11

8）葛野亮、後藤春彦、佐藤宏亮 : 都市更新期における下町への転入者の生活 順応プロセス，日本都市計画学会都市計画論文集 第 46 巻第 3 号, pp.499$504,2011.10$

9）太田尚孝、エルファディング・ズザンネ、大村謙二郎：ドイツのコーポラ ティブハウス（Baugemeinschaft）を用いた都市再生の実態と課題に関する 研究, 都市住宅学 84 号, pp.109-114, 2014.1

10）杉山昇：コーポラティブ方式による小規模再開発事業——密集市街地での 活用一, 再開発研究 No.24, pp.59-65, 2008

11）五十嵐敦子、丁志映、小林秀樹：住民主体の住まいづくりにおける NPO の支援とその可能性 一 密集市街地の共同建替え（東京都北区）の事例をも とに一, 日本建築学会大会学術講演梗概集 F-2, 都市計画, pp.109-110, 2007.8

12）高橋亮裕、川岸梅和、北野幸樹、田林映 : コーポラティブ・ハウジングに 関する研究 その 52 , 日本建築学会大会学術講演梗概集 DVD, 建築社会シ ステム, pp.209-210, 2012.9

13）金冒錫、高見沢実 : 密集市街地整備のための連担建築物設計制度の運用に 関寸る研究，日本都市計画学会都市計画論文集 第 40 巻第 1 号, pp.91-96, 2005.4

14）小浪晋、岩田賢治、赤崎弘平 : 京都市における連担建築物設計制度の初動 的運用実態, 2002 年度第 37 回日本都市計画学会学術論文集, pp.385-390, 2002.10

15）川崎興太 : 一団地型地区計画による協調建て替え誘導の実績と効果に関す る研究, 日本都市計画学会都市計画論文集第 39 巻第 2 号, pp.45-56, 2004.10

16）加藤仁美、田丸重彦 : 建築基準法第 43 条第 1 項但書許可基準の実態に関 寸る研究，都市計画第 50 巻第 3 号, pp.80-85, 2001.8

17）有田智一、岩田司：接道困難敷地の実態に対応した接道特例許可の運用の あり方，日本建築学会計画系論文集第 533 号，pp.135-142，2000.7

18）町田有司, 川岸梅和, 北野幸樹, 大村敏 : 木造密集市街地におけるまちづ くり手法に関する研究 その 1 一東京都中野区野方 $1 \cdot 2$ 丁目居住者の意 識特性について, 日本建築学会大会学術講演梗概集 F-1, 都市計画, pp.679$680,2006.9$

19）小林由佳、松原裕樹、小谷部育子、高見沢邦郎：密集市街地の共同建替え に関する実態的考察—その 2 東京都区部と神戸市における優良建築物整 備事業の比較 —, 日本建築学会大会学術講演梗概集 F-1, 都市計画, pp.175$176, \quad 1999.9$

20）小林由佳、高見沢邦郎、饗庭伸：密集市街地における建替え動向と協調建 替え概念の検討，日本都市計画学会都市計画論文集第 38 巻第 1 号, pp.13$24,2003.4$

21）山崎明子、玉川英則、中林一樹 : 街づくり事業地区における細街路整備手 法と市街地の地域的特徴との関係——東京区部における地域特性と細街路整 備諸施策のあり方に関する研究 2 , 日本建築学会計画系論文集, 第 78 巻, 第 694 号, pp.2547-2556, 2013.12

22）朴鐘玄、佐藤滋 : 木造密集市街地整備におけるまちづくり骨格道路と各種 事業・自力建替の進行実態—事業実績と自力建替からみた木造密集市街地 整備プログラムに関する研究 その 1 一, 日本建築学会計画系論文集, 第 77 巻, 第 677 号, pp.1653-1662, 2012.7

23）大村敏，川岸梅和：木造密集市街地における小規模連鎖型の街区整備に関 する研究, 日本建築学会大会学術講演梗概集 F-1, 都市計画, pp.527-528,
2005.9

24）勝又済 : 規制誘導手法を活用した密集市街地の建替え促進方策に関する研 究、規制誘導手法の活用をめぐる地方公共団体の意向, 日本都市計画学会都 市計画論文集 No.44-3, pp.625-630，2009.10.

25）織山和久，小滝晃：木造密集市街地の共同建て替えにおけるデザインコー ドについて, 日本建築学会計画論文集第 80 巻第 710 号, pp.863-872, 2015.4

26）大東真悟、村田大樹、村橋正武 : 既成市街地整備を推進する協働の仕組み に関する考察, 日本都市計画学会都市計画論文集第 38 巻第 3 号, pp.247$252,2003.10$

注

注 1) 中野区では総数 181,010 棟に対し、無接道の住宅数は 1,860 棟、 $2 \mathrm{~m}$ 末 満は 11,950 棟、 $2 \sim 4 \mathrm{~m}$ 未満は 64,340 棟にも上る。（総務庁「住宅・土地 統計調査」平成 25 年)

注 2) 中野区の土地所有状況（宅地）では、土地面積 $100 \mathrm{~m}^{2}$ 未満の土地所有 者数構成比は $46 \%$ 、うち $50 \mathrm{~m}^{2}$ 未満は $12 \%$ になる。ちなみに面積構成比で は $100 \mathrm{~m}^{2}$ 未満は $16 \%$ 、うち $50 \mathrm{~m}^{2}$ 未満は $2 \%$ である（東京都「東京の土 地 2012」)

注 3 ) 例えば、東京新聞（2013 年 12 月 20 日）「この通り（品川区戸越公園通 り）を含む約 $3.5 \mathrm{~km}$ の区間で、幅約 $20 \mathrm{~m}$ の防災道路が計画され、550 棟、 数千人が立ち退きを迫られる。ルート上にはほかにも多くの商店街が連なり、 道路によって分断されたり、通りの片側が削られる形になったりする。戦後 間もなくから六十年以上続く商店主の男性（61）は「みんな顔見知りで家族 構成まで知っている。だからこそ助け合える」と話す。「防災もその地域に合っ たやり方があるはず。コミュニティの力に頼る選択が、なぜ許されないのか」。 先月末 $(2013$ 年 11 月)、都議会に計画見直しの請願を提出した。集まった 署名は 460 人分…」

注4）例えば、長谷川工務店ではマンション標準生産システム「コンパス」シリー ズを 1973 年に開発している。

注 5）株式会社アーキネットの内部資料による。

注 6）分訮方式に比心゙、委託型組合方式はこれまで普及していない。1,000 $\mathrm{m}^{2}$ 単位のまとまった規模の対象敷地が順調に取得できる状況では、分譲マン ション会社は少数の担当者によって標準手順に従って計画・契約・施工・販 売ができるために収益性は高かった。一方、委託型組合方式では、 2 年近く もの事業期間において、委託業者は各組合員、原地権者、設計者、施工者、 金融機関、近隣住民等との膨大な調整業務に従事しながらも、業務収益は委 託手数料のみで、開発利益を得る事業方式ほどの収益性は期待されない。そ のため、この委託業務にあえて参入・継続する業者が多くなかったと考えら れる。

注 7）工事用車両は $2 \mathrm{t}$ ロング（車幅 $1.89 \mathrm{~m}$ ）を想定している。車両制限令を 㛜密に適用寸ると $3.39 \mathrm{~m}$ 以下の道路幅の区間の通行は認められないが、図 3 に表示された南台 2 丁目の区域では、右上部分以外はこの要件を満たさな い。道路後退を実施せずに共同建替えを進める場合は、対象区画群は街区下 側 $(78$ 戸 $)$ と街区上左側 (25 戸) の 2 箇所に統合せざるをえず、いずれも 大規模再開発事業となる。こうした大規模再開発型の共同建替えの事業化は 非常に困難で、車両制限令を厳格に適用寸る前提では、木造密集地域の不燃 化は、小規模建替えでも大規模再開発事業でも成立しがたい。実際には、細 街路の多い地域で車両制限令を豲格に適用寸ると工事が不可能となる実情に 鑑み、同令による通行制限を行わない自治体が少なくない（平成 24 年 12 月 5 日付広島県情報公開・個人情報保護審査会答申参照)。以上から本研究 では、工事車両の通行が何らかの形で許容されることを前提とした。この車 両制限令の緩和を制度上どう整理するかは検討課題として残される。

注 8）非整形性は、統合後の敷地のうち実質的に建物敷地として活用する部分 (敷地のうち路地状部分を除外した部分) で平面充填（任意の矩形平面によっ て隙間なく敷き詰める操作）を行う場合に必要な最小枚数に着目して評価す る。抽出箇所の平面充填には、最低 3 枚が必要だが、他の箇所はいずれも最 低 2 枚で平面充填が可能である。

注 9）X 区取引事例のうち無道路地 14 事例を同一地域・同一用途地域の接道 地に比較して平均減価率 $71.7 \%$ 。統合後は路地状敷地の減価率 $30 \%$ と地積 大の減価率 $15 \%$ の積（東京高裁判決 平成 13 年 12 月 6 日）

注 10）該当区画群は、幅員約 $1.5 \mathrm{~m}$ の通路にのみ囲まれている。

注 11）該当区画群は、幅員約 $1.6 \mathrm{~m}$ の通路のみに面し、接道条件を満たすには、 左上の接道区画まで連続して区画統合する必要がある。 
注 12）建替え後の各ユニットの面積表（単位: $\mathrm{m}^{2}$ ) は以下の通り。

\begin{tabular}{|c|c|c|c|c|c|c|c|c|c|c|c|c|}
\hline & 1 & 2 & 3 & 4 & 5 & 6 & 7 & 8 & 9 & 10 & 11 & 跸段空 \\
\hline $1 F$ & 132.6 & 48.0 & 42.0 & 47.8 & & & & & & & & 30.8 \\
\hline $2 \mathrm{~F}$ & & & & & 107.1 & 28.8 & 93.4 & 47.8 & & & & 30.8 \\
\hline $3 F$ & & & & & & 121.2 & & & 65.7 & 46.6 & 47.8 & 30.8 \\
\hline
\end{tabular}

\begin{tabular}{|l|l|l|l|l|l|l|l|l|l|l|l|l|}
\hline 合計 & 132.6 & 48.0 & 42.0 & 47.8 & 107.1 & 150.0 & 93.4 & 47.8 & 65.7 & 46.6 & 47.8 & 92.4 \\
\hline
\end{tabular}

従前・従後で専有面積は必ずしも一致はしないが、設計で調整は可能である。 また、暮らし方等に応じてユニットを組み合わせることもできる。例えば、 従前の $\mathrm{E}$ 区画地権者が元の専有面積 $84.0 \mathrm{~m}^{2}$ をほぼ同等に確保する意向であ れば、ユニット 3 と 4 を連続させて専有面積 $89.8 \mathrm{~m}^{2}$ の住戸を選ぶことがで きる。

注 13）コーポラティブハウス 8 棟の実績值は $190 \sim 270$ 千円 $/ \mathrm{m}^{2}$ 、平均 243 千円 $/ \mathrm{m}^{2}$ (2006 2014、鉄筋コンクリート造低層壁式地上階のみ、侏アー キネット)。東京のマンションでは 177 千円 $/ \mathrm{m}^{2}$ (鉄筋コンクリート造ラー メン構造 $6 \sim 9$ 階建（(財）建設物価調査会「：総研リポート特別号」 2009.4)

注 14）対象用地周辺の戸建て 14 件、アパート 12 件の賃料を築年数、駅距離、 新宿までの乗車時間、階数、専有面積で回帰分析して得られた予測式から求 めた。
注 15）試算に当たり、リバース・モーゲージ方式を想定する理由は、自己資 金状態の多寡に影響されない条件を設定して建替え事業の経済性を評価する ためである。不動産売却および元利払いの後、純資産残高がプラスであれば、 リバース・モーゲージ方式は可能である。リバース・モーゲージが成立すれ ば、自己資金ゼロの場合でも建替えには利益性があることとなる。

注 16）本研究にいう「NPV（Net Present Value）倍率」とは、事業対象地に 係る不動産について、期首及び期末の不動産価值、期間中の帰属家賃及び期 中累積純収益等の合計額を現在価值に換算し、建替えを行う場合（with）の 值の建替えを行わない場合 (without) の值に対する比を算出したものである。 現在価值とは、異時点で発生する価值を比較するために、それらを一定の割 引率 (利子率) で割り戻して現時点での価值に換算した額である。本研究に おける建替え事業に関わる価值は、期首及び期末の不動産（土地・建物）価 值、狶属家賃等の収益、など異なる時点で発生寸る様々な要素からなる。そ こで個々の地権者にとっての建替え事業及び現状のままの価值を統一的な尺 度で比較・評価するために、この現在価值を用い、建替えを行う場合の值の 建替えを行わない場合の值に対する比を算出するものとする。

注 17）東京都区部における躯体の堅牢な壁式 $\mathrm{RC}$ 造の低層集合住宅に係る実 績值から抽出したデータによる回帰結果による。 


\title{
FEASIBILITY OF BUILDING COOPERATIVE SYSTEM \\ IN AREAS WITH HIGH DENSITY OF WOODEN HOUSES
}

\author{
Akira KOTAKI* and Kazuhisa ORIYAMA** \\ * Inspector-General \\ Minister's Secretariat, Ministry of Land, Infrastructure, Transport and Tourism. \\ ** Chief Executive Officer, archinet, inc., Ph.D.
}

Fireproofing in areas with a high proportion of wooden buildings requires a method of consolidating subdivided lots that may have no connection to a road and ensuring that any rebuilding project is profitable even for small plots and irregular areas of land. The block-scale redevelopment projects implemented by developers do not suit these conditions and there are few successful results. In contrast, rebuilding projects run by housing cooperatives with the support of professional experts match the conditions and detailed simulations indicate that the results improve the benefits for all stakeholders, including the owners, their heirs, and new residents who move into the area from outside. A lender of a reverse mortgage will have the certainty of being rewarded since the higher level of security regarding the value is maintained after rebuilding. The main factor that generates profits is the added value due to land consolidation in which lots with no connecting road are converted to lots with road access, and the consolidation of undervalued irregular shaped plots of land makes them suitable for rebuilding. The results of these simulations of the general conditions for rebuilding indicate that the land reference price for a targeted area should more than $551,000 \mathrm{yen} / \mathrm{m}^{2}$ and the areal ratio of lots without road access should be over $80 \%$ of the consolidated land. These general conditions apply to most areas with a high density of wooden buildings in Tokyo and are peculiar to the most difficult areas for rebuilding. The remaining issues are policies that promote negotiation and consensus among the land-owners and conditions that ensure professional support for rebuilding cooperatives. 